\title{
Sperm quality and selected biochemical markers of seminal plasma at the beginning of the reproductive period of common carp, Cyprinus carpio $\mathrm{L}$.
}

\author{
Beata Irena Cejko • Sławomir Krejszeff • Sylwia Judycka • \\ Beata Sarosiek • Mariola Dietrich • Dariusz Kucharczyk • \\ Radosław Kajetan Kowalski
}

Received: 5 February 2013/Accepted: 9 July 2013/Published online: 23 July 2013

(C) The Author(s) 2013. This article is published with open access at Springerlink.com

\begin{abstract}
Changes in semen quality and selected biochemical markers were analyzed during a week of spawning season of common carp Cyprinus carpio L. Semen was obtained twice, on May 30 and on June 7, and each time it was collected $24 \mathrm{~h}$ after hormonal stimulation using Ovopel [(D-Ala ${ }^{6}$, Pro $\left.^{9} \mathrm{NEt}\right)-\mathrm{mGnRH}+$ metoclopramide] in 1 pellet $\mathrm{kg}^{-1}$. The total volume of semen $(\mathrm{ml})$, volume of semen per $\mathrm{kg}$ of body weight ( $\mathrm{ml} \mathrm{kg}^{-1}$ b.w.), sperm concentration $\left(\times 10^{9} \mathrm{ml}^{-1}\right)$, total number of sperm per $\mathrm{kg}$ of body weight $\left(\times 10^{9} \mathrm{~kg}^{-1}\right.$ b.w.), $\mathrm{pH}$ of semen, $\mathrm{pH}$ of seminal plasma, seminal plasma osmotic pressure $\left(\mathrm{mOsm} \mathrm{kg}^{-1}\right)$ and the total protein content in seminal plasma $\left(\mathrm{mg} \mathrm{ml}^{-1}\right)$ were determined. A $10 \mathrm{mM}$ Tris buffer containing $100 \mathrm{mM} \mathrm{NaCl}$ with $0.5 \%$ BSA (pH 9.0, osmolality $200 \mathrm{mOsm} \mathrm{kg}{ }^{-1}$ ) was used to activate sperm. The following computer-assisted sperm analysis (CASA) parameters were determined: percentage of motile sperm (MOT, $\%$ ), progressively motile sperm (PRG, \%), curvilinear velocity (VCL, $\mu \mathrm{m} \mathrm{s}^{-1}$ ), straightline velocity (VSL, $\mu \mathrm{m} \mathrm{s}^{-1}$ ), movement linearity (LIN, \%), wobbling index (WOB, \%), amplitude of lateral head displacement $(\mathrm{ALH}, \mu \mathrm{m})$ and beat cross-frequency $(\mathrm{BCF}, \mathrm{Hz})$. The volume of semen per $\mathrm{kg}$ of $\mathrm{BW}$, total number of sperm per $\mathrm{kg}$ of $\mathrm{BW}$ and semen $\mathrm{pH}$ were significantly lower at the second semen sampling compared to the first semen sampling. Volume of semen at the second sampling correlated positively with CASA parameters. A lack of differences among CASA parameters between both collection periods indicates good quality of carp sperm hormonally stimulated with Ovopel twice at a 1 -week interval.
\end{abstract}

Keywords Common carp · Cyprinus carpio L. S Sperm · CASA

B. I. Cejko $(\bowtie) \cdot$ S. Judycka · B. Sarosiek · M. Dietrich · R. K. Kowalski

Department of Gamete and Embryo Biology, Institute of Animal Reproduction and Food Research, Polish Academy of Sciences, ul. Bydgoska 7, 10-243 Olsztyn, Poland

e-mail: b.cejko@pan.olsztyn.pl

S. Krejszeff · D. Kucharczyk

Department of Lake and River Fisheries, Faculty of Environmental Sciences, University of Warmia and Mazury, ul. Oczapowskiego 5, 10-719 Olsztyn, Poland 


\section{Introduction}

Seasonal fertility, which characterizes some Teleostei species such as common carp Cyprinus carpio L., Eurasian perch Perca fluviatilis (L.) or Caspian roach Rutilus rutilus caspicus, influences the reproductive potential of females as well as males (Christ et al. 1996; Alavi et al. 2010; Golpour et al. 2013). In males, this is expressed by the volume of semen, the number of sperm and their motility and changes over the period of the spawning season. For most species belonging to the Cyprinidae family, the peak of the spawning season occurs during the spring-summer months, which are often accompanied by significant changes in average daily temperatures. These variations lead to disturbances in the reproductive cycle and subsequently a decrease in the reproductive performance of males broodstock (Bobe and Labbé 2010; Mylonas et al. 2010).

The common carp is the main species of fish farmed in Poland. This fish has gained popularity among fish breeders and producers due to the various compositions of feeds it consumes, humans' high ability to absorb nutrients from them and its fast growth rate. It is also a valuable game fish, while a long history of its production (reaching back to the Middle Ages) and traditions connected with its consumption have caused it to be of interest to consumers. Due to the growth of the human population and need for valuable sources of protein such as fish, the breeding of fish species for consumption, including carp, is of great importance (Balon 1995).

The availability of mature male common carp broodstock is the first step in breeding practices conducted on a production scale (Szabó et al. 2000). Obtaining carp sperm and eggs under natural conditions is very problematic, so the breeding of these fish is performed mainly under controlled conditions. Because spermatogenesis in carp has a continuous nature, hormonal stimulation is used to aid in semen collection (both during and out of spawning season) (Kucharczyk et al. 2008). Because of the strong mechanism blocking the release of gonadotropins in cyprinids (including carp), complex preparations enriched with substances which have an antagonistic effect on dopamine such as Ovopel [(D-Ala ${ }^{6}$ Pro $^{9}$ NEt)-metoclopramide] (Horváth et al. 1997; Brzuska and Białowąs 2003; Kucharczyk et al. 2008), Ovaprim [(D-Arg ${ }^{6}$ Pro $^{9}$ NEt)-domperidone] (Haniffa et al. 2007) or Dagin [(D-Arg ${ }^{6}$ Pro $^{9}$ NEt)-metoclopramide (Brzuska 2005, 2006) are in use.

The ability to use male carp multiple times during the spawning season may have a significant meaning, not only from the practical point of view (fewer times fish need to be caught and handled) but above all due to the economic costs of maintaining the actual male broodstock. However, there is a lack of data regarding the possibility of using male carp multiple times over the spawning season. Therefore, the aim of the presented work was to determine the reproductive capabilities of carp hormonally stimulated with Ovopel twice during a 1-week interval at the beginning of the spawning season.

\section{Materials and methods}

Semen collection and broodstock manipulation

Adult male common carp $(n=18)$ with a weight range of $0.54-1.3 \pm 0.20 \mathrm{~kg}$ were taken from earth ponds at the Knieja Fishery Farm (Częstochowa-southern Poland) during the spawning season and transported to the aquarium hall of the Department of Lake and River Fisheries in Olsztyn (northeastern Poland). After transport, the fish were placed in closed circuit tanks $\left(1,000 \mathrm{dm}^{3}\right)$ at $18{ }^{\circ} \mathrm{C}$. Within a week, the water temperature was raised to 
20-21 ${ }^{\circ} \mathrm{C}$. After adaptation, the males were hormonally stimulated by intraperitoneal injection using [(D-Ala ${ }^{6}$ Pro $\left.^{9} \mathrm{NEt}\right)-\mathrm{mGnRH}+$ metoclopramide] Ovopel $\left(1\right.$ pellet $\left.\mathrm{kg}^{-1}\right)$. After 24-h post-hormonal application on 30 May, the fish were taken from the tanks (Cejko et al. 2011) and floy-tagged, and then semen was collected (first semen sampling) with sterile syringes by abdominal massage. The fish were anesthetized with 2-phenoxyethanol (Merc, Darmstadt, Germany) at a dose of $0.5 \mathrm{ml}^{-1}$ of water. After semen collection, the fish were placed back in the pools for 1 week. After a 1-week interval, male common carp were stimulated again with Ovopel ( 1 pellet $\mathrm{kg}^{-1}$ ), and on 7 June (after 24-h post-hormonal application), semen was obtained again (second semen sampling) from each male individually. Special care was taken during the first and second periods of semen collection to avoid urine, feces or blood contamination.

Semen volume and sperm count

The total volume of semen $(\mathrm{ml})$ was measured directly after its collection using syringes calibrated every $0.01 \mathrm{ml}$, and the amount of semen was recorded. Before semen collection, males were weighted $(\mathrm{kg})$, and together with the values of total volume of semen were used to calculate semen volume per $\mathrm{kg}$ of fish body weight $\left(\mathrm{ml} \mathrm{kg}^{-1}\right.$ b.w.). Sperm concentration $\left(\times 10^{9} \mathrm{ml}^{-1}\right)$ was determined in accordance with the procedure described by Ciereszko and Dabrowski (1993). The semen was diluted 2,000 times in two replicates with $0.7 \% \mathrm{NaCl}$, and the absorption of the samples was measured using a Beckman DU-640 spectrophotometer (Analytical Instruments, LLC, Golden Valley, MN, USA) at a wavelength of $\lambda=530 \mathrm{~nm}$. The absorption values were then placed into the analytical curve equation $(y=107.28 x-0.2075$, where $x$ equals absorption measurement results) previously prepared for carp using a Bürker's chamber (cytometric method). The total sperm production $\left(\times 10^{9}\right)$ and the males' BW were used to estimate the total number of sperm per kg of body weight $\left(\times 10^{9} \mathrm{~kg}^{-1}\right.$ b.w.). Semen and sperm parameters were determined on 30 May (first collection) and on 7 June (second collection).

Sperm motility parameters

Sperm motility was analyzed using the computer-assisted sperm analysis (CASA) system. A $10 \mathrm{mM}$ Tris buffer containing $100 \mathrm{mM} \mathrm{NaCl}$ with $0.5 \%$ albumin (BSA) (pH 9.0 and osmolality of $200 \mathrm{mOsm} \mathrm{kg}{ }^{-1}$ ) was used as the activating solution (Cejko et al. 2013). Sperm motility was activated by mixing $1 \mu \mathrm{l}$ of sperm with $25 \mu \mathrm{l}$ of the activating solution buffer, and $1 \mu \mathrm{l}$ of the activating sperm was transported to the microscope slide (12 wells of $30 \mu \mathrm{l}$ depth and 5-mm-diameter Teflon-coated slide glass) (Tekdon, Inc., Myakka City, FA, USA). Recording of sperm movement was made approximately $6 \mathrm{~s}$ after sperm movement activation. Sperm motility was registered using a Basler A202K camera (Basler, Ahrensburg, Germany) integrated with an Olympus BX51 microscope (Plan FL N 20×/0.5 $\mathrm{NH}$ ph1 lens) (Olympus, Tokyo, Japan) at a recording speed of 46.6 frames $\mathrm{s}^{-1}$. The first 200 frames from each recording were analyzed using the CRISTMAS program (Image House Ltd., Denmark). CASA analysis was used to determine the percentage of motile sperm (MOT, \%) and progressively motile sperm (PRG, \%), curvilinear velocity (VCL, $\mu \mathrm{m} \mathrm{s}^{-1}$ ) and straight-linear velocity (VSL, $\mu \mathrm{m} \mathrm{s}^{-1}$ ), movement linearity (LIN, \%), the wobbling index (WOB, \%), amplitude of lateral head displacement (ALH, $\mu \mathrm{m})$ and beat cross-frequency $(\mathrm{BCF}, \mathrm{Hz})$. The picture settings and parameters of its analysis were as follows: AcquireTime delay: 0; ImageFields max 40; ImagesPerRecord 200; SpermTracks min: 10,000; ClassMethod: VAP; CombineLevel: 10; NoMoveLng: 5; 
TrackImmotileLevel: 5; TrackMotileLevel: 25; TrackProgressiveSTRLevel: 80; TrackTailsUse: True; VelocityMax: 400. During CASA analysis, milt samples were kept on ice $\left(+4{ }^{\circ} \mathrm{C}\right)$. For each semen sample, sperm motility parameters were measured in duplicate, and the averages for each sample and every CASA parameter were determined at the first and second semen sampling.

Semen $\mathrm{pH}$ and seminal plasma parameters

The $\mathrm{pH}$ of semen and seminal plasma was determined using the Orion Star 3 meter equipped with an Orion Ross Ultra electrode (Thermo Scientific, MA, USA). In order to obtain seminal plasma, semen samples were centrifuged twice (supernatant from first centrifugation was centrifuged again to ensure that no sperm cells were present in seminal plasma) at $10.000 \times g$ for $10 \mathrm{~min}$. Total protein content was determined in seminal plasma using the Lowry et al. (1951) method, and osmotic pressure was measured on a Löser apparatus manufactured by Minitüb, Abfüll—u. Labortechnik GmbH\&Co.KG (Germany). Semen $\mathrm{pH}$, seminal plasma $\mathrm{pH}$, seminal plasma osmotic pressure and total protein content were determined after the first and at the second period of semen sampling.

Statistical analysis

All values were estimated as mean and standard deviation $( \pm \mathrm{SD})$. The volume of semen per $\mathrm{kg}$ of $\mathrm{BW}$, sperm concentration, total number of sperm per $\mathrm{kg}$ of $\mathrm{BW}$, sperm motility (CASA parameters), semen $\mathrm{pH}$, seminal plasma $\mathrm{pH}$, seminal plasma osmotic pressure and total protein content determined at the first (30 May) and at the second (7 June) semen sampling were compared using the paired $t$ test. Before statistical analyses were made, data were tested for normal distribution. Pearson's linear correlation was applied to identify the relation between values of semen, seminal plasma and sperm motility parameters using the CASA system with exception of total number of sperm, sperm volume and sperm concentration for which relation, linear regression model was used. Statistical analysis was conducted using the GraphPad Prism program (GraphPad Software Inc., San Diego, CA, USA).

\section{Results}

Semen volume and sperm count

A significant decrease in the volume of semen (per $\mathrm{kg}$ of $\mathrm{BW}$ ) and the total number of sperm (per kg of BW) were observed at the second semen sampling compared to the first sampling $(P<0.05$; Table 1$)$. After the second period of semen sampling, the tendency of decreasing sperm concentration was also observed, although the values of this parameter did not significantly differ from values recorded on the first sampling $(P>0.05$; Table 1$)$.

Sperm motility parameters

Sperm motility parameters determined by CASA system at the second semen sampling were similar to sperm motility parameters determined at the first sampling $(P>0.05$; Table 2). The volume of semen (per $\mathrm{kg}$ of $\mathrm{BW}$ ) recorded at the second period of semen 


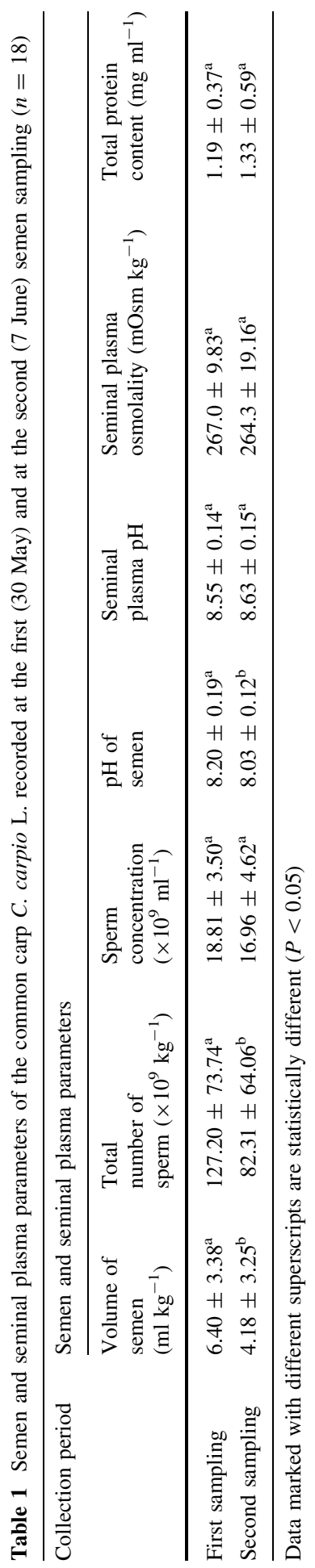




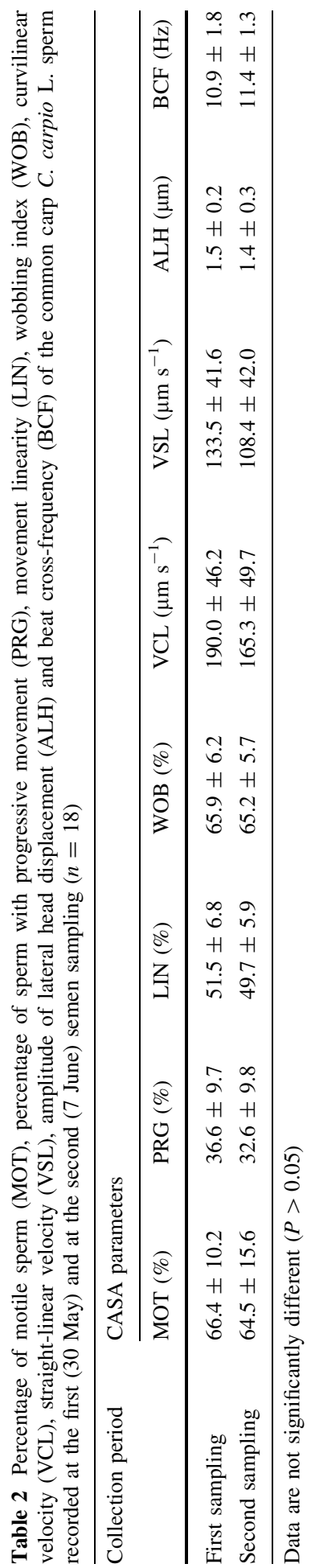


collection was positively correlated with all CASA parameters with the exception of ALH and BCF (Table 4).

\section{Semen $\mathrm{pH}$ and seminal plasma parameters}

The semen $\mathrm{pH}$ determined at the first semen sampling was significantly higher compared to the semen $\mathrm{pH}$ recorded at the second semen sampling $(P<0.05$; Table 1$)$. The other plasma parameters such as seminal plasma $\mathrm{pH}$, seminal plasma osmotic pressure and total protein content in seminal plasma were at a similar level at the first and at the second semen samplings without statistical differences $(P>0.05$; Table 1$)$. At the first sampling, a significant correlation was recorded between the osmolality of seminal plasma and $\mathrm{pH}$ of semen (0.609), seminal plasma $\mathrm{pH}(0.558)$, volume of semen and seminal plasma $\mathrm{pH}(-0.754)$ and total number of sperm and seminal plasma $\mathrm{pH}(-0.773)$ (Table 3$)$. At this time, CASA

Table 3 Relation between semen and seminal plasma parameters of the common carp C. carpio L. recorded at the first (30 May) and at the second (7 June) semen sampling

\begin{tabular}{|c|c|c|c|c|c|c|c|}
\hline \multirow{2}{*}{$\begin{array}{l}\text { Semen and } \\
\text { seminal plasma } \\
\text { parameters }\end{array}$} & \multirow{2}{*}{$\begin{array}{l}\text { Collection } \\
\text { period }\end{array}$} & \multicolumn{6}{|c|}{ Semen and seminal plasma parameters } \\
\hline & & $\begin{array}{l}\mathrm{pH} \text { of } \\
\text { semen }\end{array}$ & $\begin{array}{l}\text { Seminal } \\
\text { plasma } \mathrm{pH}\end{array}$ & $\begin{array}{l}\text { Volume } \\
\text { of semen }\end{array}$ & $\begin{array}{l}\text { Sperm } \\
\text { concentration }\end{array}$ & $\begin{array}{l}\text { Total } \\
\text { number } \\
\text { of sperm }\end{array}$ & $\begin{array}{l}\text { Osmotic } \\
\text { pressure }\end{array}$ \\
\hline \multirow[t]{2}{*}{$\begin{array}{l}\text { Seminal } \\
\text { plasma pH }\end{array}$} & $\begin{array}{l}\text { First } \\
\text { sampling }\end{array}$ & 0.439 & & & & & \\
\hline & $\begin{array}{l}\text { Second } \\
\text { sampling }\end{array}$ & $0.583^{*}$ & & & & & \\
\hline \multirow[t]{2}{*}{$\begin{array}{l}\text { Volume of } \\
\text { semen }\end{array}$} & $\begin{array}{l}\text { First } \\
\text { sampling }\end{array}$ & -0.223 & $-0.754 * * *$ & & & & \\
\hline & $\begin{array}{l}\text { Second } \\
\text { sampling }\end{array}$ & $-0.625^{* *}$ & $-0.505^{*}$ & & & & \\
\hline \multirow[t]{2}{*}{$\begin{array}{l}\text { Sperm } \\
\text { concentration }\end{array}$} & $\begin{array}{l}\text { First } \\
\text { sampling }\end{array}$ & -0.210 & -0.244 & $0.379 * *$ & & & \\
\hline & $\begin{array}{l}\text { Second } \\
\text { sampling }\end{array}$ & -0.210 & $-0.569 *$ & 0.023 & & & \\
\hline \multirow[t]{2}{*}{$\begin{array}{l}\text { Total number } \\
\text { of sperm }\end{array}$} & $\begin{array}{l}\text { First } \\
\text { sampling }\end{array}$ & -0.232 & $-0.773 * * *$ & $0.865 * * *$ & $0.319 *$ & & \\
\hline & $\begin{array}{l}\text { Second } \\
\text { sampling }\end{array}$ & $-0.481 *$ & $-0.809 * * *$ & $0.582 * * *$ & 0.217 & & \\
\hline \multirow[t]{2}{*}{$\begin{array}{l}\text { Osmotic } \\
\text { pressure }\end{array}$} & $\begin{array}{l}\text { First } \\
\text { sampling }\end{array}$ & $0.609 * *$ & $0.558^{*}$ & -0.299 & 0.025 & -0.346 & \\
\hline & $\begin{array}{l}\text { Second } \\
\text { sampling }\end{array}$ & -0.257 & -0.218 & 0.211 & 0.145 & 0.042 & \\
\hline \multirow[t]{2}{*}{$\begin{array}{l}\text { Total protein } \\
\text { content }\end{array}$} & $\begin{array}{l}\text { First } \\
\text { sampling }\end{array}$ & -0.112 & -0.189 & -0.089 & 0.013 & -0.057 & -0.198 \\
\hline & $\begin{array}{l}\text { Second } \\
\text { sampling }\end{array}$ & -0.119 & 0.242 & 0.071 & 0.257 & 0.175 & -0.402 \\
\hline
\end{tabular}

Pearson's linear correlation was applied to identify the relation between values of semen, seminal plasma and spe $\overline{\bar{r}}$ motility parameters using the CASA system with exception of total number of sperm, sperm volume and sperm concentration for which relation, linear regression model was used

* $P<0.05$; ** $P<0.01$; *** $P<0.001, n=18$ 
parameters including MOT $(P<0.01)$, VCL $(P<0.05)$, VSL $(P<0.05)$ and ALH $(P<0.001)$ were correlated with the $\mathrm{pH}$ of semen (Table 4$)$. At the second period of semen collection, the volume of semen and the total number of sperm (per $\mathrm{kg}$ of b.w.) were correlated with semen $\mathrm{pH}(-0.625$ and -0.481$)$ and seminal plasma $\mathrm{pH}(-0.505$ and -0.809) (Table 3). Almost all CASA parameters (apart from ALH and BCF) recorded at this time correlated significantly with the volume of semen (Table 4).

\section{Discussion}

The results of the present study indicate that at the beginning of the common carp reproductive period, it is possible to stimulate males with Ovopel twice after a 1-week interval. However, the second hormonal injection is less effective than the first one. A significant decrease in the volume of semen, number of sperm and $\mathrm{pH}$ of semen was observed at the second semen sampling ( 7 June) compared to the first sampling (30 May). On the other hand, a lack of differences among CASA parameters between both collection periods indicates good quality of carp sperm hormonally stimulated with Ovopel twice at a 1 -week interval.

In species bred in earth ponds, such as the common carp, difficulties during the last stage of oocyte and spermatocyte maturation are observed, which have been referred to as "reproductive dysfunctions" (Podhorec and Kouril 2009). Hormonal stimulation leads to increased reproductive efficiency of male broodstock and guarantees the synchronization of ovulation and spermiation and is a good starting point to solving problem with gametes maturation (Warnecke and Pluta 2003; Kucharczyk et al. 2008). In common carp males, the application of Ovopel ( 1 pellet $\mathrm{kg}^{-1}$ ) enables semen to be obtained even after $72 \mathrm{~h}$, but the semen volume and sperm number at this time are significantly lower than values noted after $24 \mathrm{~h}$ (Cejko et al. 2011). This indicates that in common carp males, latency time is rather short and semen should be taken no longer than $24 \mathrm{~h}$ after hormonal treatment (Toth et al. 1995; Christ et al. 1996; Cejko et al. 2011). The presented study indicated that in comparison to the first Ovopel treatment, the repeated stimulation of males with this preparation resulted in decreased semen volume and total number of sperm. Our results are similar to results presented by Christ et al. (1996) where the volume of semen and sperm count were lower in June in comparison with the values of this parameters recorded in May although differences between these parameters were not observed.

In salmonid fish, the last stage of sperm maturation takes place in the sperm ducts where sperm acquire motility potential (Kołdras et al. 1996; Morisawa et al. 1993). This process is connected with $17 \alpha$-hydroxyprogesterone under the influence of gonadotropin secretion which stimulates testicular somatic cells. 17 $\alpha$-hydroxyprogesterone changed into $17 \alpha, 20 \beta$-dihydroxy-4-progesterone stimulating the secretion of bicarbonates, the physiological response to which is the increase in the $\mathrm{pH}$ of semen (Morisawa and Morisawa 1988). In turn, the increase in semen $\mathrm{pH}$ in sperm ducts leads to increased cyclic AMP thanks to which sperm assumes the ability to move (Morisawa et al. 1993). The positive correlation between the $\mathrm{pH}$ of semen and CASA parameters (MOT, VCL, VSL and ALH) recorded on the first semen sampling indicates, similarly to the salmonids, that during this time, the sperm motility of common carp is significantly dependent on the $\mathrm{pH}$ of semen. The cascade of physiological processes, taking place under the influence of gonadotropins which leads to sperm attaining reproductive capabilities, justifies the application of hormonal stimulation in carp reproduction. On the other hand, in common carp, some CASA parameters, i.e., VCL and VSL, exhibited a slight seasonal trend; therefore, changes are often noticed between 


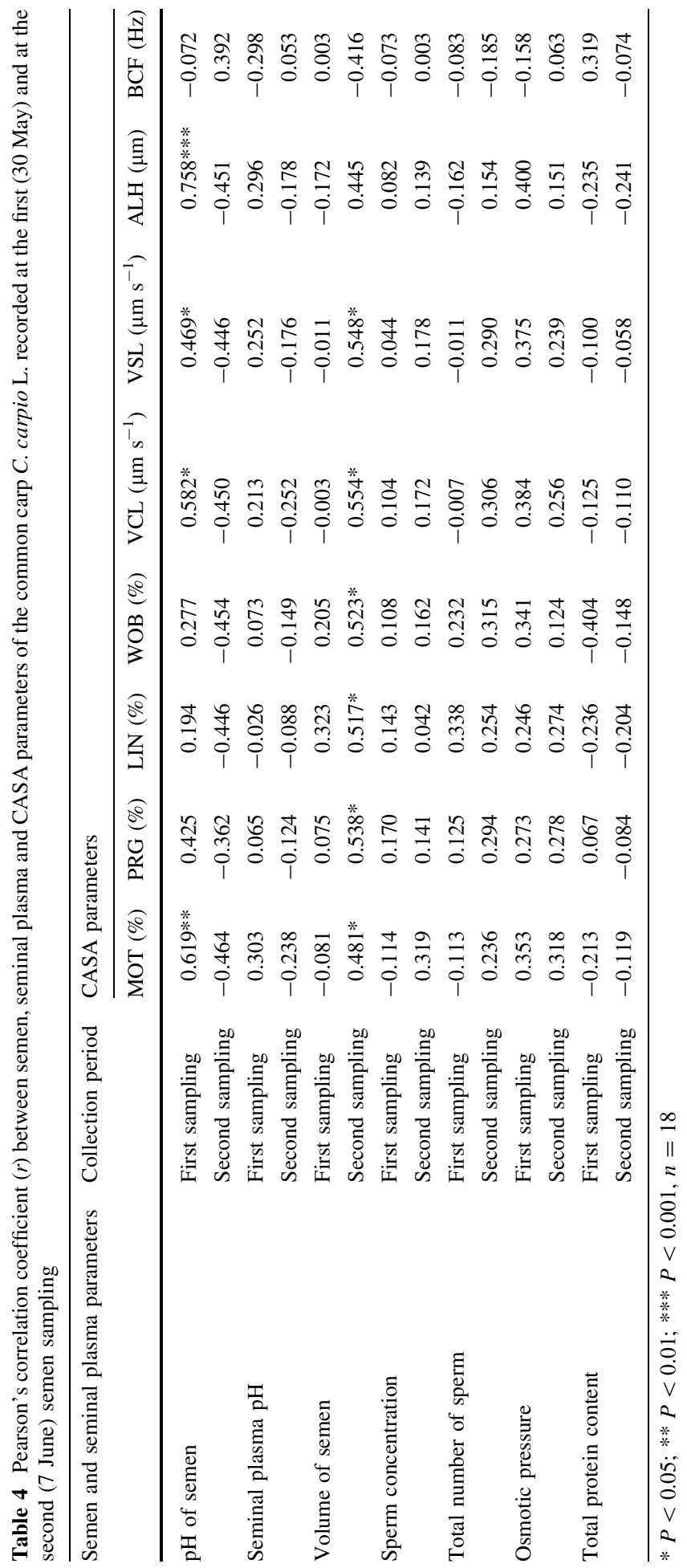


sperm parameters in dependence of period of semen collection (Christ et al. 1996). In the presented study, sperm velocity parameters such as VCL and VSL determined at the first sampling were at a similar level as compared to the results presented by Christ et al. (1996). In May, VCL and VSL values were estimated at a level of about 190 and $130 \mu \mathrm{m} \mathrm{s}^{-1}$.

Seminal plasma osmotic pressure of cyprinid fish contains up to $230-346 \mathrm{mOsm} \mathrm{kg}^{-1}$ (Alavi and Cosson 2006), whereas the $\mathrm{pH}$ of seminal plasma of this fish does not usually fall under the value of 8.0 (Lahnsteiner et al. 1996; Cejko et al. 2012). In the case of salmonid fish, a positive correlation between the $\mathrm{pH}$ of seminal plasma and sperm motility has been confirmed. The alkaline $\mathrm{pH}$, similar to the $\mathrm{pH}$ of seminal plasma or ovary liquid of these fish, increases the percentage of motile sperm and their ability to fertilize eggs (Billard 1981). A significant correlation between the $\mathrm{pH}$ of seminal plasma and MOT, LIN and VCL values was also found in bleak Alburnus alburnus (L.) (Lahnsteiner et al. 1996). The presented results do not confirm the existence of dependencies between the biochemical parameters of carp seminal plasma and parameters of sperm motility in either the first or second period of semen collection. This can signify that the most important factor in determining the motility of sperm in carp is the semen $\mathrm{pH}$, the increase of which leads to increased cAMP which in turn activates sperm motility. It is plausible that the $\mathrm{pH}$ of seminal plasma may also constitute a factor responsible for sperm motility. Decreased semen $\mathrm{pH}$ may be caused by urine contamination which is sometimes observed in species subjected to the traditional method of semen collection (abdominal massage) such as carp (Perchec et al. 1995). In our study, a positive correlation between the osmolality of seminal plasma and $\mathrm{pH}$ of semen could support this hypothesis. Semen contamination by urine has also been observed in tench Tinca tinca (L.) (Cejko et al. 2010) and rainbow trout Oncorhynchus mykiss (Walbaum) (Glogowski et al. 2000). From a practical point of view, all contamination of semen (urine, feces, mucus) should be eliminated. Problems with contamination can be resolved by the catheterization of male broodstock as an alternative method in relation to the traditional way of semen collection (Glogowski et al. 2000). Another possibility to protect semen from urine contamination is using an immobilizing solution during semen collection (Rodina et al. 2004).

The present study indicates quality sperm at the beginning of the common carp reproductive period such as 1 week. Although decreased semen volume and total number of sperm were observed at the second semen sampling ( 7 June) compared to the first sampling (30 May), CASA parameters were unchanged between both collection periods. This indicates sufficient quality of sperm and their potential ability to fertilize eggs. Decreased semen $\mathrm{pH}$ at the second sampling compared to the first sampling can be connected with semen contamination by urine. Therefore, the catheterization of males may be a better technique for semen collection in comparison with the standard method (abdominal massage).

Acknowledgments The presented study is supported by the National Science Centre Grant No. N 311 351239 and funds appropriated to the Institute of Animal Reproduction and Food Research.

Open Access This article is distributed under the terms of the Creative Commons Attribution License which permits any use, distribution, and reproduction in any medium, provided the original author(s) and the source are credited.

\section{References}

Alavi SMH, Cosson J (2006) Sperm motility in fishes. (II) Effects of ions and osmolality: a review. Cell Biol Int 30:1-14 
Alavi SMH, Rodina M, Hatef A, Stejskal V, Policar T, Hamáčková J, Linhart O (2010) Sperm motility and monthly variations of semen characteristics in Perca fluviatilis (Teleostei: Percidae). Czech J Anim Sci 55(4):174-182

Balon EK (1995) Origin and domestication of the wild carp, Cyprinus carpio: from Roman gourmets to the swimming flowers. Aquaculture 129:3-48

Billard R (1981) Short-term preservation of sperm under oxygen atmosphere in rainbow trout, Salmo gairdneri. Aquaculture 23:287-293

Bobe J, Labbé C (2010) Egg and sperm quality in fish. Gen Comp Endocrinol 165:535-548

Brzuska E (2005) Artificial spawning of carp (Cyprinus carpio L.): differences between females of Polish strain 6 and Hungarian strain W treated with carp pituitary homogenate, Ovopel or Dagin. Aquacult Res 36:1015-1025

Brzuska E (2006) Artificial propagation of female Hungarian strain 7 carp (Cyprinus carpio) after treatment with carp pituitary homogenate, Ovopel or Dagin. Czech J Anim Sci 51(3):132-141

Brzuska E, Białowąs H (2003) Artificial spawning of carp, Cyprinus carpio (L.). Aquacult Res 33:753-765

Cejko BI, Żarski D, Targońska K, Krejszeff S, Kucharczyk D, Glogowski J (2010) Osmolality of seminal plasma as an indicators of milt contamination with urine based on the example of the tench Tinca tinca (L.). Pol J Nat Sci 25(3):287-298

Cejko BI, Kowalski RK, Kucharczyk D, Żarski D, Targońska K, Glogowski J (2011) Effect of time after hormonal stimulation on semen quality indicators of common carp, Cyprinus carpio (Actinopterygii: Cypriniformes: Cyprinidae). Acta Ichthyol Piscat 41(2):75-80

Cejko BI, Kowalski RK, Żarski D, Dryl K, Targońska K, Chwaluczyk R, Kucharczyk D, Glogowski J (2012) The influence of the length of time after hormonal treatment with [(D-Ala ${ }^{6}$, Pro ${ }^{9} \mathrm{NEt}$ )$\mathrm{mGnRH}+$ metoclopramide] i.e. Ovopel on barbel Barbus barbus (L.) milt quality and quantity indicators. J App Ichthyol 28:249-253

Cejko BI, Sarosiek B, Kowalski RK, Krejszeff S, Kucharczyk D (2013) Application of computer-assisted sperm analysis in selecting the suitable solution for common carp, Cyprinus carpio L. sperm motility. J World Aquacult Soc 44(3):466-472

Christ SA, Toth GP, McCarthy HW, Torsella JA, Smith MK (1996) Monthly variation in sperm motility in common carp assessed using computer-assisted sperm analysis (CASA). J Fish Biol 48:1210-1222

Ciereszko A, Dąbrowski K (1993) Estimation of sperm concentration of rainbow trout, whitefish and yellow perch using a spectrophotometric technique. Aquaculture 109:367-373

Glogowski J, Kwasnik M, Piros B, Dabrowski K, Goryczko K, Dobosz S, Kuzminski H, Ciereszko A (2000) Characterization of rainbow trout milt collected with a catheter: semen parameters and cryopreservation success. Aquacult Res 31:289-296

Golpour A, Akhoundian M, Khara H, Rahbar M, Dadras H (2013) Changes of sperm quality parameters in Caspian roach (Rutilus rutilus caspicus) during spawning migration. Czech J Anim Sci 58(3):117-124

Haniffa MA, Benziger Allen PS, Arockiaraj Jesu A, Nagarajan M, Siby P (2007) Breeding behavior and embryonic development of koi carp (Cyprinus carpio). Taiwania 52:93-99

Horváth L, Szabó T, Burke J (1997) Hatchery testing of GnRH analogue-containing pellets on ovulation in four cyprinid species. Pol Arch Hydrobiol 44(1/2):221-226

Kołdras M, Loir M, Maisse G, Le Gac F (1996) Study of the composition of seminal plasma fluid and of sperm motility along the genital track, during a spawning season, in the rainbow trout (Oncorhynchus mykiss). Aquat Living Resour 9:337-345

Kucharczyk D, Targońska K, Hliwa P, Kwiatkowski M, Krejszeff S, Perkowski J (2008) Reproductive parameters of common carp (Cyprinus carpio L.) spawners during natural and season and out-ofseason spawning. Rep Biol 8:285-289

Lahnsteiner F, Berger B, Weismann T, Patzner RA (1996) Motility of spermatozoa of Alburnus alburnus (Cyprinidae) and its relationship to seminal plasma composition and sperm metabolism. Fish Physiol Biochem 15:167-179

Lowry OH, Rosenbrough NJ, Farr AR, Randall KJ (1951) Protein measurement with the Folin phenolreagnt. J Biol Chem 193:265-275

Morisawa S, Morisawa M (1988) Induction of potential for sperm motility by bicarbonate and $\mathrm{pH}$ in rainbow trout and chum salmon. J Exp Biol 136:13-22

Morisawa S, Ishida K, Okuno M, Morisawa M (1993) Roles of $\mathrm{pH}$ and cyclic adenosine monophosphate in the acquisition of potential for sperm motility during migration from the sea to the river in chub salmon. Mol Reprod Dev 34:420-426

Mylonas CC, Fostier A, Zanuy S (2010) Broodstock management and hormonal manipulations of fish reproduction. Gen Comp Endocrinol 165:516-534

Perchec GP, Cosson J, Andrč F, Billard R (1995) Degradation of the quality of carp sperm by urine contamination during stripping. Aquaculture 129:135-136 
Podhorec P, Kouřil J (2009) Induction of final oocyte maturation in Cyprinidae fish by hypothalamic factors: a review. Vet Med 54:97-110

Rodina M, Cosson J, Gela D, Linhart O (2004) Kurokura solution as immobilizing medium for spermatozoa of tench (Tinca tinca L.). Aquacult Res 12:119-131

Szabó T, Szabó R, Urbányi B, Horváth L (2000) Review of the results of common carp (Cyprinus carpio) breeding at a large-scale hatchery. Rep Dom Anim 35:89-94

Toth GP, Christ SA, McCarthy HW, Torsella JA, Smith MK (1995) Computer-assisted motion analysis of sperm from the common carp. J Fish Biol 47:986-1003

Warnecke D, Pluta HJ (2003) Motility and fertilizing capacity of frozen/thawed common carp (Cyprinus carpio L.) sperm using dimethyl-acetamide as the main cryoprotectant. Aquaculture 215:167-185 